\title{
Study on Extraction Technology and Functional Activity of Sika Deer Velvet(Residue) Collagen
}

\author{
Shiru Bo ${ }^{1, a}$, Xiaolin Zhang 2, b, Quankai Wang 3, c \\ ${ }^{1}$ Jilin agricultural science and technology college Jilin 132101 \\ ${ }^{2}$ Jilin agricultural science and technology college Jilin 132101 \\ ${ }^{3}$ Jilin agricultural science and technology college Jilin 130000 \\ aemail, ${ }^{\text {bemail, }}$ 'email,
}

Keyword: Sika Deer Velvet Antler, Collagen, Functional Activity

\begin{abstract}
Objective:Extraction method and functional activity of collagen that is extracted from residue that is insoluble in any medium polar solvent by ultrasonic extraction andsupercritical $\mathrm{CO}_{2}$ extraction are studied. Finally the optimal enzymolysis conditionsare obtained.Methods: Quantitative content of collagen in deer antler (residue) by quantitate hydroxyproline. Sika deer antler collagen is prepared by enzymolysis of papain. According to single factor test and the orthogonal design, the optimal enzymatic conditions aredetermined by the extraction rate of collagen as evaluation indicator. And functional activity are tested which include antioxidant capacity, hydroxyl free radical scavenging ability, DPPH scavenging ability of the test and keratinocyte cell test.Results: The content of collagen in the deer antler (residue) is 4.5795\%,the best extraction process is $2 \%$ optimum enzyme dosage , $\mathrm{PH}$ 6.0, 1:20 solid-liquid ratio, enzymolysis time $66 \mathrm{~h}$ at $10^{\circ} \mathrm{C}$. The extraction rate of collagen of the deer antler is $54.59 \%$. The protein is collagen by UV spectroscopy.Functional tests are showed a good functionality and growth and reproduction capacity.
\end{abstract}

\section{Introduction}

The velvet that is nor ossified pilose antler of sika deer or red deer has unique biological activity and chemical composition. The traditional product processing of getting the deer velvet is backward,which lead to low effective active ingredient and utilization. Collagen physiological function that is lose weight, blood pressure and blood fat, immune regulation, antioxidant and so on is widely used in medicine, food, cosmetics and other fields. Currently collagen of raw materials are mostly animal skin, bone, waste leather in which there are more Heavy metals, pesticides and other harmful substances on the market.Because of velvet growth cycle less than six months,there are less harmful substances. In this paper, extraction method and functional activity of collagen that is extracted from residue that is insoluble in any medium polar solvent by ultrasonic extraction and supercritical $\mathrm{CO}_{2}$ extraction are studied .

\section{Experimental Materials}

Main Raw Materials and Reagents. Residue that is insoluble in any medium polar solvent(Yitong Ji Yun deer industry), perchloric acid, isopropyl alcohol, n-propanol, chloramine $\mathrm{T}$, stannous chloride, L-hydroxyproline standard, bovine serum albumin, papain(80 million U /g), $\mathrm{FeSO}_{4}, \mathrm{H}_{2} \mathrm{O}_{2}$,DPPH (Changchun aoke Biological Technology Ltd), Other reagents are of analytical grade.

Main Equipment. GB204 electronic analytical balance(SARTORIUS Ltd), PH meter( Shanghai 
huyue Science and Technology Instrument Ltd), W201B constant temperature water bath(Shanghai Shensheng Technology Ltd), UV2800 UV Visible Spectrophotometer(Shimadzu), CHRiST vacuum freeze dryer(CHRiST), High speed refrigerated centrifuge(Sigma), Dialysis bag(Changchun aokeBiological Technology Ltd), $\mathrm{CO}_{2}$ incubator(Shanghai hecheng equipment Manufacturing Ltd)

\section{Experimental Method}

Determination of Collagen Content. L(-)-hydroxyproline standard curve is established according to GB9695.23-90 “Content determination of L-hydroxyproline of meat and meat products". According to the determination of hydroxyproline, hydroxyproline is released When the velvet are hydrolyzed by stannous chloride. Absorbance and the content of hydroxyproline in sika deer velvet are tested. Quantitative calculation of the content of collagen in the sika deer velvet through the terrestrial animals commonly used 7.1 as a conversion factor ${ }^{[2]}$.

Pickling. According to pre-experiment and single factor test,the optimum conditions for decalcification of sika deer velcet are $4 \% \mathrm{HCL}, 1: 15$ solid-liquid ratio, $48 \mathrm{~h}$ pickling time at $4^{\circ} \mathrm{C}$. The decalcification rate can reach $96.42 \%$ In this condition.

Impurity Removal. In this experiment, $\mathrm{NaCl}$ solution is selected as the main reagent for the dephosphorization protein. According to pre-experiment and single factor test,the optimum conditions for protein removal of sika deer velcet are 4\% HCL, 1:10 solid-liquid ratio, $12 \mathrm{~h}$ removal time.

Extraction with Papain and Acid. In this experiment, papain and citric acid are combined to extract to Keep alive and low antigenic at low temperature. The enzymolysis liquid has been rancid at $25^{\circ} \mathrm{C}$ through pre-experimentation .So the temperature of enzymatic extraction is $10^{\circ} \mathrm{C}$.

According to pre-experiment and single factor test, the factors and levels of orthogonal test are determined. Through the orthogonal design scheme of $\mathrm{L}_{9}\left(3^{4}\right)$, screen the optimum match of enzyme dosagel, $\mathrm{PH}$, solid-liquid ratio and enzymatic time by the extraction rate of collagen and other proteins content as evaluation indicator.

Preparation of standard curve of other proteins: $50 \mathrm{mg}$ bovine serum albumin at concentration of $0 \mathrm{mg} / \mathrm{ml} 、 0.2 \mathrm{mg} / \mathrm{ml} 、 0.3 \mathrm{mg} / \mathrm{ml} 、 0.6 \mathrm{mg} / \mathrm{ml} 、 0.9 \mathrm{mg} / \mathrm{ml} 、 1.2 \mathrm{mg} / \mathrm{mldetermine} \mathrm{absorbance} \mathrm{at} \mathrm{wave} \mathrm{length}$ of $280 \mathrm{~nm}$. The standard curve with the absorbance A and the content of bovine serum albumin is the ordinate and abscissa. The standard curve equation: $\mathrm{y}=0.5844 \mathrm{x}-0.036, \mathrm{R}^{2}=0.9985$.

Tab 1 Levels of factors for extract collagen by papain with citric acid

\begin{tabular}{c|cccc}
\hline factor & (A)Enzyme dosage (\%) & (B)PH value & (C)Volume ratio & (D)time $(\mathrm{h})$ \\
\hline 1 & $1.0 \%$ & 5 & $1: 12$ & 66 \\
2 & $2.0 \%$ & 6 & $1: 15$ & 72 \\
3 & $3.0 \%$ & 7 & $1: 20$ & 78 \\
\hline
\end{tabular}

Purification and Detection of Crude Protein. All the collagen is salted under neutral conditions, when the concentration of sodium chloride is $4.0 \mathrm{~mol} / \mathrm{L}$ or $20 \%{ }^{[4]}$. Nacl is slowly added the sika deer antler collagen enzymatic solution . Fully stir and static 10-24h, $9000 \mathrm{rpm}$ speed centrifugation. The precipitate is collected and dissolved in $0.5 \mathrm{~mol} / \mathrm{L}$ acetic acid. Dialyse by 0.5 mol / L acetic acid in order to remove the salt from the precipitate. The concentration of non-collagen decreased to below $5 \%$ and vacuum freeze.

The material by dialysing is dissolved with $0.5 \mathrm{~mol} / \mathrm{L}$ glacial acetic acid and diluted with distilled water.The purity of velvet collagen is tested at wave length of $280 \mathrm{~nm}$ by UV Visible Spectrophotometer ${ }^{[5]}$. 
Functional Determination. Determination of free radical activity of superoxide anion by pyrogallol automatic oxidation ${ }^{[6]}$.

Determination of self-oxidation rate of blank samples: $0.1 \mathrm{~mL}$ constant temperature of $45 \mathrm{mmol} / \mathrm{L}$ pyrogallol solution is added to mixed solution that are $5 \mathrm{~mL}$ Tris- $\mathrm{HCl}$ buffer with $\mathrm{pH} 8.20$ and 0.5 $\mathrm{ml}$ water which is constant to $10 \mathrm{~min}$ at $25^{\circ} \mathrm{C}$.Absorbance is tested at wave length of $280 \mathrm{~nm}$ by UV Visible Spectrophotometer every 30s and continue ten times and self-oxidation rate $\mathrm{V}_{1}$ is calculated.

Determination of self-oxidation rate of samples: $0.1 \mathrm{~mL}$ constant temperature of $45 \mathrm{mmol} / \mathrm{L}$ pyrogallol solution is added to mixed solution that are $5 \mathrm{~mL}$ Tris-HCl buffer with $\mathrm{pH} 8.20$ and 0.5 $\mathrm{ml} 10 \mathrm{mg} / \mathrm{mL}$ sample solution which is constant to $10 \mathrm{~min}$ at $25^{\circ} \mathrm{C}$.Absorbance is tested at wave length of 280nm by UV Visible Spectrophotometer every 30s and continue ten times and self-oxidation rate $\mathrm{V}_{1}$ is calculated ${ }^{[7]}$.

The inhibition rate is calculated from the autoxidation rate of pyrogallol, The formula is as follows: Inhibition rate $=\left(\mathrm{V}_{1}-\mathrm{V}_{0}\right) / \mathrm{V}_{1} \times 100 \%,\left(\mathrm{~V}_{0}\right.$ and $\mathrm{V}_{1}$ are the autoxidation rate of pyrogallol of blank and sample groups). [8].

According to table 2,the absorbance is calculated at wavelength of $510 \mathrm{~nm}$ by spectrophotometry

Tab 2 Sample test of $\mathrm{OH}^{-}$scavenging ability

\begin{tabular}{l}
\hline Absorbance $\quad$ Solution composition \\
\hline $\mathrm{A}_{0} \quad 1 \mathrm{~mL} 9 \mathrm{mmol} / \mathrm{L}$ salicylic acid-Ethanol Solution $+1 \mathrm{~mL} \mathrm{9mmol} / \mathrm{L}$ \\
$\mathrm{FeSO}_{4}+1 \mathrm{~mL}$ Distilled water $+1 \mathrm{~mL} 8.8 \mathrm{mmol} / \mathrm{L} \mathrm{H}_{2} \mathrm{O}_{2}$ \\
$\mathrm{~A}_{1} 1 \mathrm{~mL} 9 \mathrm{mmol} / \mathrm{L}$ Salicylic acid-ethanol solution $+1 \mathrm{~mL} \mathrm{9mmol} / \mathrm{L}$ \\
$\mathrm{FeSO}_{4}+1 \mathrm{~mL} 10 \mathrm{mg} / \mathrm{mL}$ Sample solution $+1 \mathrm{~mL} 8.8 \mathrm{mmol} / \mathrm{L} \mathrm{H}_{2} \mathrm{O}_{2}$ \\
$\mathrm{~A}_{2} \quad 1 \mathrm{~mL} 9 \mathrm{mmol} / \mathrm{L}$ Salicylic acid - ethanol solution $+1 \mathrm{~mL} 9 \mathrm{mmol} / \mathrm{L}$ \\
FeSO $_{4}+1 \mathrm{~mL}$ distilled water $+1 \mathrm{~mL} 10 \mathrm{mg} / \mathrm{mL}$ Sample solution \\
\hline
\end{tabular}

The removal rateiscalculatedas:clearance rate $=\frac{A_{0}-\left(A_{1}-A_{2}\right)}{A_{0}} \times 100 \%$

$\mathrm{A}_{0}$ indicates the absorbance of the blank control solution

$\mathrm{A}_{1}$ indicates the absorbance of the solution to be measured

$\mathrm{A}_{2}$ indicates the absorbance of the liquid background of the sample to be measured without the developer

(1) Mixed solution that are $2 \mathrm{~mL}$ DPPH solution and $2 \mathrm{~mL} 70 \%$ ethanol solution measured at wave length of $516 \mathrm{~nm}$ by $70 \%$ ethanol as a reference and $\mathrm{A}_{1}$ isrecorded.

(2) Mixed solution that are $2 \mathrm{~mL} 70 \%$ of ethanol solution and $2 \mathrm{~mL} 10 \mathrm{mg} / \mathrm{mL}$ of the sample solution measured at wave length of $516 \mathrm{~nm}$ by $70 \%$ ethanol as a substance and $\mathrm{A}_{2}$ is recorded.

(3) Mixed solution that are $2 \mathrm{~mL} 10 \mathrm{mg} / \mathrm{mL}$ of the sample solution, $2 \mathrm{~mL}$ DPPH solution and $2 \mathrm{~mL}$ $70 \%$ ethanol solution measured at wave length of $516 \mathrm{~nm}$ by $70 \%$ ethanol as a substance and $\mathrm{A}_{3}$ is recorded.

Calculation formula of the removal rate $=\frac{1-\left(A_{3}-A_{2}\right)}{A_{1}} \times 100 \%$ Biological activity and Sample different concentrations is tested which are antioxidant capacity, hydroxyl scavenging ability and DPPH scavenging ability.

Keratinocytes Test. Keratinocytes that are collected after processing are cultivated of 2-3 days at $37^{\circ} \mathrm{C}$ in $5 \% \mathrm{CO}_{2}$ incubator.Aftercells conically multiply, the velvet collagen with the same concentration is cultivated which is coated on a $35 \mathrm{ml}$ culture dish as a substrate. After 2hours, That cell density of Keratinocytes reached $4 \times 10^{4} / \mathrm{cm}^{2}$ are add and cultivated of 10hours. Bioactivity of 
pilose antlercollagen is tested by microscope. Cell growth is an evaluation index ${ }^{[10]}$.

\section{Results and Analysis}

Determination of Collagen Content. The linear relationship between absorbance and $\mathrm{L}(-)$-hydroxyproline concentration is: $\mathrm{y}=0.2322 \mathrm{x}+0.0012\left(\mathrm{R}^{2}=0.9998\right)$.

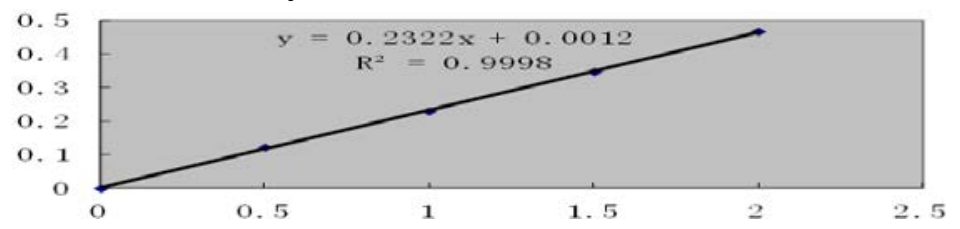

Fig. 1 The standard curve of L(-)-hydroxyProlin

According to the formula: $C=\frac{\mathrm{X} \times 250 \times \frac{200}{\mathrm{~V}_{1}} \times 10^{16}}{\mathrm{~m}} \times 100=\frac{5 \mathrm{X}}{\mathrm{mV}_{1}}$, the content of $\mathrm{L}(-)-$ hydroxyproline in the deer antler is $\mathbf{0 . 6 4 5 \%}$. The content of collagen in the deer antler Is $4.5795 \%$. Under the experimental conditions by the conversion factor 7.1 .

$\mathrm{C}$ on behalf of the content of $\mathrm{L}(-)$ - hydroxyproline in the deer antler (\%)

$\mathrm{X}$ on behalf of Check the corresponding $\mathrm{L}(-)$ - hydroxyproline from the standard curve $(\mathrm{ug} / \mathrm{mL})$

$\mathrm{m}$ on behalf of weigh the quality of the deer velvet $(\mathrm{g})$

$\mathrm{V}_{1}$ on behalf of the volume of the filtrate is drawn from $200 \mathrm{~mL}$ volumetric flask,(mL)

Determination of Optimum Enzymatic Hydrolysis Conditions of Papain. According to single factor test, the factors and levels of orthogonal test are determined. Through the orthogonal design scheme of $\mathrm{L}_{9}\left(3^{4}\right)$, screen the optimum match of enzyme dosagel, $\mathrm{PH}$, solid-liquid ratioand enzymatic time.

Tab 3 The results of orthogonal experiment

\begin{tabular}{ccccccc}
\hline Processingnumber & Enzymedosage & PH & Volumeratio & time & Collagen(mg) & Protein(mg) \\
\hline 1 & 1 & 1 & 1 & 1 & 135.14 & 28.82 \\
2 & 1 & 2 & 2 & 2 & 138.71 & 29.09 \\
3 & 1 & 3 & 3 & 3 & 139.07 & 28.68 \\
4 & 2 & 1 & 2 & 3 & 146.96 & 29.86 \\
5 & 2 & 2 & 3 & 1 & 148.19 & 30.66 \\
6 & 2 & 3 & 1 & 2 & 148.13 & 30.47 \\
7 & 3 & 1 & 3 & 2 & 149.69 & 32.07 \\
8 & 3 & 2 & 2 & 3 & 141.13 & 29.26 \\
9 & 3 & 3 & 1 & 1 & 140.89 & 29.21 \\
K1 & 151.25 & 158.16 & 159.92 & 159.42 & & \\
K2 & 162.74 & 160.42 & 159.11 & 159.90 & & \\
K3 & 165.46 & 160.87 & 159.42 & 159.13 & & \\
$\mathrm{k}_{1}$ & 50.42 & 52.32 & 53.04 & 53.14 & & \\
$\mathrm{k}_{2}$ & 54.25 & 52.72 & 53.30 & 53.80 & & \\
$\mathrm{k}_{3}$ & 55.15 & 53.79 & 54.47 & 53.38 & & \\
$\mathrm{R}$ & 4.74 & 0.89 & 0.43 & 0.24 & & \\
\hline
\end{tabular}


Tab 4 Anova table

\begin{tabular}{cccccc}
\hline $\begin{array}{l}\text { The source of } \\
\text { cariance }\end{array}$ & $\begin{array}{c}\text { square of } \\
\text { deviance }\end{array}$ & $\begin{array}{c}\text { Degrees of } \\
\text { freedom }\end{array}$ & variance & F value & Significance \\
\hline A & 37.93 & 2 & 18.97 & 446.35 & $\mathrm{P}<0.01$ \\
B & 1.39 & 2 & 0.70 & 16.38 & $\mathrm{P}<0.1$ \\
C & 0.28 & 2 & 0.14 & 3.34 & $\mathrm{P}>0.1$ \\
D & 0.085 & 2 & 0.043 & 1.00 & $\mathrm{P}>0.1$ \\
\hline
\end{tabular}

$$
\mathrm{F}_{0.1(2,2)}=9.00
$$

$\mathrm{F}_{0.05(2,2)}=19.00$

$\mathrm{F}_{0.01(2,2)}=99$

Based on the orthogonal test results, the order of influence is $\mathrm{A}>\mathrm{B}>\mathrm{C}>\mathrm{D}$ that enzyme dosagel $>\mathrm{PH}>$ solid-liquid ratio $>$ enzymatic time. The results of variance analysis show that the enzyme dosagelhavet effect on experimental results. PH is statistical significance. From the point of view of the protein, enzyme dosagel is significant statistical significance. The best combination of factors is $A_{2} B_{2} C_{3} D_{1}$ in which the dosage of $2 \%$ enzyme dosagel, $\mathrm{PH}$ 6.0,1:20 solid-liquid ratio, 66h enzymatic time. The extraction rate of collagen is $56.59 \%$.

\section{Sika Deer Antler Collagen UV Analysis Results.}

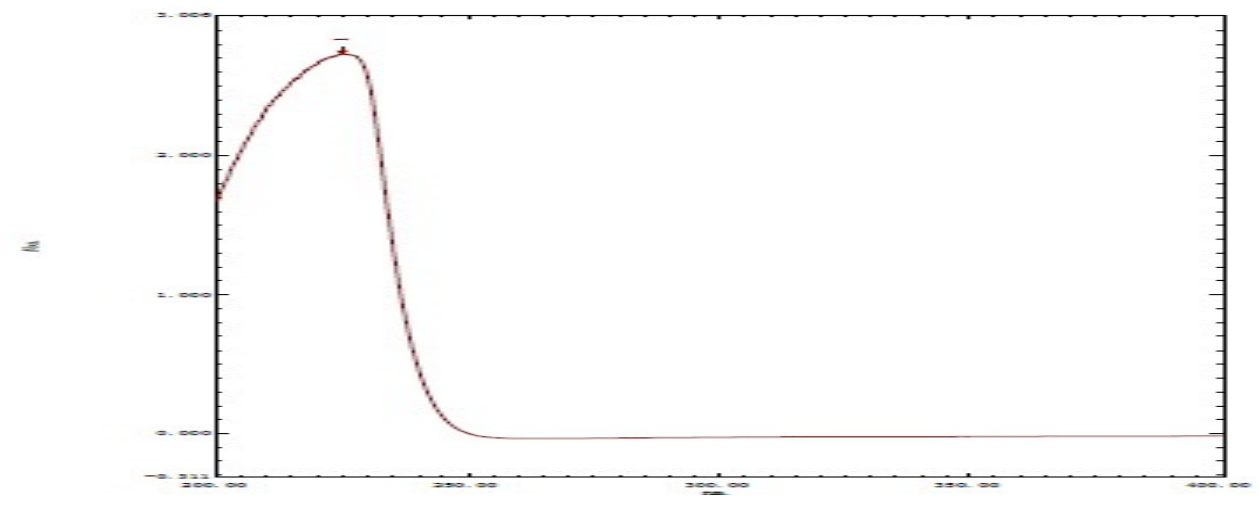

Fig.2 Sika Deer Velvet collagen UV scan

The test results are shown the protein is high purity collagen,because there is a strong absorption peak at $225 \mathrm{~nm}$ and a very low peak at 250-290 nm.

Functional Determination. Sika deer antler collagen solution is respectively diluted to four different concentrations that are $10 \mathrm{mg} / \mathrm{mL} 、 20 \mathrm{mg} / \mathrm{mL} 、 30 \mathrm{mg} / \mathrm{mL} 、 \quad 40 \mathrm{mg} / \mathrm{mL}$ and test absorbance $\left(A_{1} 、 A_{2} 、 A_{3} 、 A_{4}\right)$.Physiological functions are detected which are antioxidant capacity, hydroxyl free radical scavenging ability and DPPH scavenging ability by $0.05 \mathrm{mg} / \mathrm{mL}$ VC as control and compare the scavenging of different concentrations of the sample itself.

Tab 5 the scavenging results of Sika Deer Velvet collagen on the $\mathrm{O}^{2-}$

\begin{tabular}{cccccc}
\hline species & $\mathrm{A}_{1}$ & $\mathrm{~A}_{2}$ & $\mathrm{~A}_{3}$ & $\mathrm{~A}_{4}$ & $\mathrm{VC}$ \\
\hline clearance rate $(\%)$ & 25.96 & 27.42 & 28.63 & 28.71 & 38.83 \\
\hline
\end{tabular}

Tab 6 the scavenging results of Sika Deer Velvet collagen on the $\mathrm{OH}^{-}$

\begin{tabular}{cccccc}
\hline species & $\mathrm{A}_{1}$ & $\mathrm{~A}_{2}$ & $\mathrm{~A}_{3}$ & $\mathrm{~A}_{4}$ & $\mathrm{VC}$ \\
\hline clearance rate $(\%)$ & 30.21 & 35.53 & 38.64 & 40.07 & 88.61 \\
\hline
\end{tabular}


Table 7 the scavenging results of Sika Deer Velvet collagen on the DPPH

\begin{tabular}{cccccc}
\hline species & $\mathrm{A}_{1}$ & $\mathrm{~A}_{2}$ & $\mathrm{~A}_{3}$ & $\mathrm{~A}_{4}$ & $\mathrm{VC}$ \\
\hline clearance rate $(\%)$ & 29.06 & 40.27 & 44.39 & 45.61 & 88.61 \\
\hline
\end{tabular}

Physiological functional tests are showed there are a good functionality.With the increase in the concentration of collagen deer antler collagen, physiological functions that are the scavenging ability of $\mathrm{O}^{2-}, \mathrm{OH}^{-}$and DPPH radicals gradually grow.

\section{Keratinocytes Test}
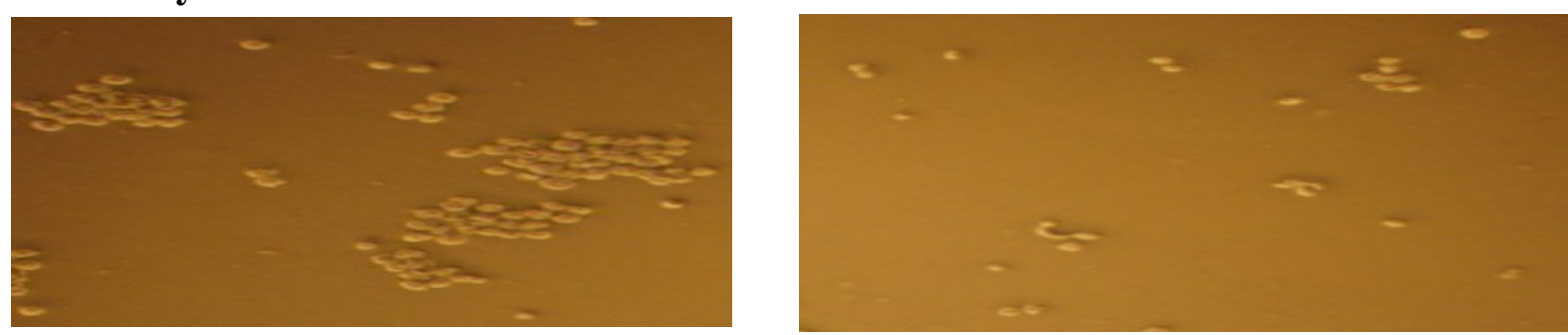

Fig.3 Culture of keratinocytes on spermatid collagenFig.4 Petri dish

The figs3, 4 are showed that the cells are cultured on the deer antler collagen have good growth and reproduction ability. The collagen which Biological activity of is not lost has reproduction capacity.

\section{Conclusion}

Through the optimization of the extraction process for the deer antler (residue),better purity of collagen is obtained. The collagen has the role of promoting cell regeneration in accordance with functional research.

The research still need further study and discussion.For instance: (1) Increase the use of specific products in order to large-scale production of sika deer antler collagen to product.(2)Find the characteristic active ingredient of the deer antler,make sure a characteristic activity factor and extract.(3)Strengthen the pharmacological research of the sika deer antler,detection of each pharmacological effect whichare produced by which componentt of the velvet.

\section{Acknowledgements}

Fund Project: Project:Jilin Agricultural Science and Technology College Youth Fund Project (119012015002)

\section{References:}

[1]WangJiazheng, Fan Ming. Protein Technology Handbook [M] Science Press, 2000.8.

[2]GB 9695.23-90 "Determination of L (-) - hydroxyproline in meat and meat products"

[3]Yongjing,Yu.FujimotoMitsuji(ed.),Liu Ping(translation).Science and Technology of Collagen [M].Shanghai College of Traditional Chinese Medicine, 1992.

[4]JiangTingda,Collagen and Collagen [M]. Chemical Industry Press, 2006.2.

[5]Tao Wei Sun,LiWei\&JiangYongming, etc. Protein Molecular Basis [M] Higher Education Press, 1995.10: 251.

[6]GuoXuefeng, Yue Yongde\&Tang Feng, et al.Evaluation of antioxidant capacity of bamboo leaf 
extract by clearing superoxide anion free radical method[J].SpectroscopyandSpectral Analysis,2008,28 (8): 1823-1826.

[7]MIAOZhi-wei, ZHOU Wei-hong\&LIU Xiao-lan, et al. Synthesis,characterization and activity determination of superoxide dismutase model compounds[J].Chinese Journal of Organic Chemistry, 1999,19,537-541.

[8]Gordon,M.H. The meachnism of antioxidant action in vitro[J].Food antioxida-nts,1990,1-18

[9]DENG Sheng-guo, DENG Ze-yuan\&HUANGLi.Study on Antioxidant Activity of Flavonoids in Lotus Leaves [J].Food Science and Technology 2006.7,274-276.

[10]StuartZhenqiang, Wu Junzheng, editor. Cell culture [M]. Xi'an: World Book Publishing Company, 1996, 69-83. 